\title{
Bio-ecological aspects of the hermit crab Paguristes calliopsis (Crustacea, Diogenidae) from Anchieta Island, Brazil
}

\author{
RENATA BIAGI, ANDREA L. MEIRELES and FERNANDO L. MANTELATTO \\ Departamento de Biologia, Faculdade de Filosofia, Ciências e Letras de Ribeirão Preto (FFCLRP) \\ Programa de Pós-Graduação em Ciências - Área: Biologia Comparada \\ Universidade de São Paulo (USP), Av. Bandeirantes, 3900 \\ 14040-901 Ribeirão Preto, SP, Brasil
}

Manuscript received on March 23, 2005; accepted for publication on November 24, 2005; presented by LuCIA MENDONÇA PREVIATO

\begin{abstract}
In southern Atlantic studies on hermit crab biology are scanty considering the local biodiversity. In this way, some population features of Paguristes calliopsis Forest and Saint Laurent, 1968 such as size frequency distribution, sex ratio and shell occupation in the natural environment were studied. Specimens were collected by means of scuba methods in the infralittoral area of the Anchieta Island. A total of 116 individuals were analyzed. Size measurements (minimum; maximum; mean shield length \pm sd, respectively) were $0.8 ; 4.5$; $2.76 \pm 0.79 \mathrm{~mm}$ for males and $2.28 \pm 0.36 \mathrm{~mm}$ for females. The sex ratio was 1.47:1 in favor of males which prevailed in the largest size classes. The hermit crabs occupied shells from eleven gastropod species and Cerithium atratum (Born 1778) was significantly the most occupied one (75.86\%). Significant correlations were not obtained in all regression analysis, demonstrating sexual differences on fitting of the occupied shells. In the studied area $P$. calliopsis population is small if compared with the other hermit crab populations. The shell utilization varies as a function of shell availability and hermit crabs interspecific competition, in relation to the other coexistent species.
\end{abstract}

Key words: Diogenidae, Paguristes, population, shell occupation.

\section{INTRODUCTION}

Hermit crabs represent a very important macrozoobenthic group within the intertidal and sublittoral communities. They have an important role in the marine trophic chain (Fransozo et al. 1998). Consequently, this group represents promising study because the establishment of these animals in such habitats derives from the evolution of adaptive population strategies (Mantelatto and Sousa 2000). Sympatric hermit crab populations are usually link-

Correspondence to: F.L. Mantelatto, Ph.D.

E-mail: flmantel@usp.br ed to the marine environment features regulated by the shell partitioning (Gherardi and Nardone 1997). According to Miller (1967), the resource partition can directly affect the distribution of individuals, possibly reducing the abundance of the different populations.

Hermit crabs have also been included in numerous reports of decapods from Central and South America. However, few species have received more than brief attention. Despite the reports about Brazilian shore populations of some hermit species (see Mantelatto and Sousa 2000 for review) they represent promising material for study on compara- 
tive population biology and ecology with specimens from different areas. Furthermore, regarding the shell utilization process some differences have been highlighted between populations from island and continental coastal zones (Garcia and Mantelatto 2000).

The hermit crabs fauna of the islands of the Ubatuba region, northern coast of São Paulo State, are poorly known, despite the fact that the decapod crustacean communities in this area have been well investigated (Hebling et al. 1994, NegreirosFransozo et al. 1997, Fransozo et al. 1998, Mantelatto and Fransozo 2000). Studies on the composition of the anomuran fauna of the infralittoral bottoms of Anchieta Island pointed out the occurrence of nine hermit crab species that correspond to more than $40 \%$ and $20 \%$ of the species recorded for the São Paulo State and Brazilian coast, respectively (Mantelatto and Garcia 2002).

Three groups of hermit crabs in particular (i.e., the genera Pagurus, Paguristes, and the "Pylopagurus-like" species), have been a difficult group to study because there are many still-undescribed species and considerable identification problems between specialists and nonspecialists alike (Hendrickx and Harvey 1999). The genus Paguristes is represented by more than 100 species distributed in all tropical and subtropical oceans, occurring from the intertidal zones to moderate depths (Provenzano-Jr 1978).

Paguristes calliopsis Forest and Saint Laurent 1968 is one of the poorly studied species which occurs in shallow waters of the Western Atlantic (Guianas and Brazil) until 60m depth, generally on bottoms covered by algae. Studies on this species are limited to the geographical distribution (Melo 1999 for review). As far as we know there is no information available about population structure of this species. In the present study some biological features of $P$. calliopsis are reported; sex ratio, size frequency distribution and shell occupation were analyzed. This information is important to understand the biology of this crab in the region, as well as some other aspects concerning its life cycle and the relationship with coexistent species in the studied area.

\section{MATERIALS AND METHODS}

SAMPLING AND SAMPLE ANALYSIS

Paguristes calliopsis individuals were obtained by monthly samples from October to December 1998 in the infralittoral area of South Beach of Anchieta Island $\left(23^{\circ} 33^{\prime} \mathrm{S}, 45^{\circ} 05^{\prime} \mathrm{W}\right)$. The area was recently declared a marine protected zone within the São Paulo State.

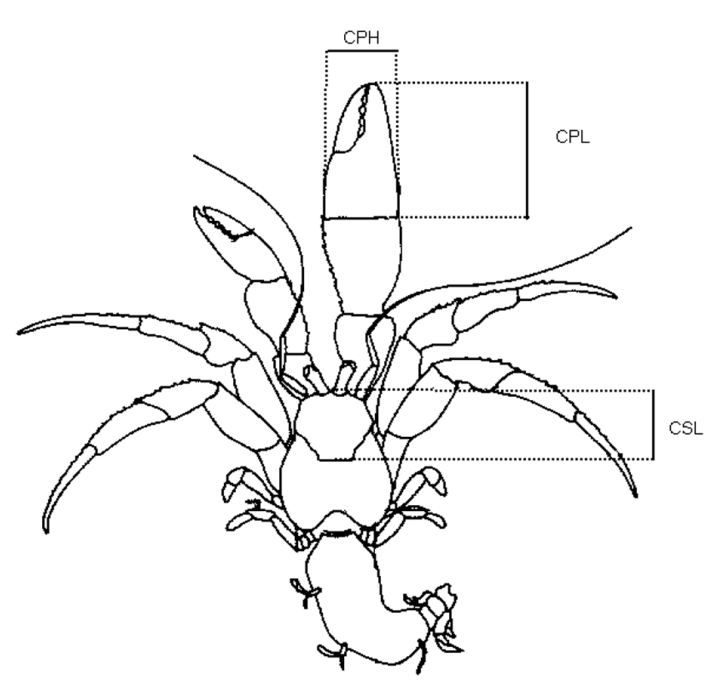

Fig. 1 - General scheme for hermit crab size dimensions (CSL = cephalothoracic shield length; $\mathrm{CPL}=$ chelar propodus length; $\mathrm{CPH}=$ chelar propodus height) (Modified from Lancaster 1988).

Samples were made during the daytime by three persons using diving equipment. Each diving inspections lasted $30 \mathrm{~min}$ covering the rocky and sandy area of about $850 \mathrm{~m}^{2}$. All hermit crab individuals found were captured by hand and maintained on collection bags while underwater. The specimens were identified on board, frozen and transported to the laboratory. Each individual was removed from the occupied shell, weighed (Wet Weight, WW) and measured on the basis of cephalothoracic shield length (CSL), chelar propodus length (CPL) and height (CPH) (Fig. 1). Measurements were made with a caliper rule $(0.1 \mathrm{~mm})$ or, 
in the case of the small individuals, by drawing utilizing the camera lucida. After analysis the hermit crabs were deposited in the Crustacean Collection of the Biology Department of FFCLRP (CCDB Catalogue number: 1615 to 1618 ) in the University of São Paulo.

Size frequency distributions were analyzed adopting the 0.5 class interval according to the Sturges formula $\left(K=1+\log _{2} n\right.$; where $K=$ number of classes, $\mathrm{n}=$ total number of individuals analyzed). Sex ratio values were estimated also. The chi-square test $\left(\chi^{2}\right)$ was used to evaluate the sex ratio and to compare male and female percentage. The size distribution frequency was tested by the KolmogorovSmirnov normality test (KS). The mean sizes of individuals of both sexes were compared by the Mann-Whitney test (Zar 1996).

\section{STUDY ON THE OCCUPIED SHELLS}

Shell species were identified according to Rios (1994) and with the help of taxonomist as Dr. Osmar Domaneschi from the Bioscience Institute of the University of São Paulo. The following measurements were made: Shell Dry Weight (SDW), Shell Aperture Width (SAW) and Shell Aperture Length (SAL). Shell internal volume (SIV) was measured by the method of Mantelatto and Garcia (2000), determining the volume of sand (diameter $=0.25-0.125 \mathrm{~mm}$ ) required to fill the empty shell. The median size of the occupied shells species was compared by the Mann-Whitney test (Zar 1996). The chi-square test $\left(\chi^{2}\right)$ was used to compare the occupancy percentage of shell species by hermit crabs sexes. The analyses were evaluated only for those shells occupied by more than 3 individuals. To determine correlations between hermit crab dimensions and shell variables, regressions and correlation coefficients were computed. The level of significance was chosen at 0.05 for all the statistical tests.

\section{RESULTS}

A total of 116 individuals was collected and analyzed: 69 males (59.48\%) and 47 females (40.52\%)
(30 non-ovigerous and 17 ovigerous females) (Table I).

Both male and female sizes were normally distributed (KS=0.082; $\mathrm{P}<0.05)$ (Fig. 2). The mean size of males was significantly $(\mathrm{P}<0.05)$ larger than the mean size of non-ovigerous females. Sexual dimorphism was recorded by the presence of males in the largest size classes. The size-frequency histogram show a clear prevalence of specimens measuring 1.5-3.5 mm CSL, with highest modal size ranging from 2.5 to $3.5 \mathrm{~mm}$ in CSL for males and from 2.0 to 3.0 in CSL for ovigerous and non-ovigerous females.

The overall sex ratio was $1.47: 1$ in favor of males and significantly different from the expected $1: 1\left(\chi^{2}=4.17 ; \mathrm{P}<0.05\right)$. In the largest size $(2.5$ to $4.5 \mathrm{~mm} \mathrm{CSL})$ the proportion of males increased, reaching values of $100 \%$ in the classes 3.5 to $4.5 \mathrm{~mm}$. The females prevailed at size class $4(2.0$ to $2.5 \mathrm{~mm}$ ) (Fig. 2), and the sex ratio value was statistically different from the expected $1: 1\left(\chi^{2}=\right.$ 8.10; $\mathrm{P}<0.05)$. Significant difference in favor of males $\left(\chi^{2}=14.73 ; \mathrm{P}<0.05\right)(10: 1)$ was obtained only in the size class $6(3.0-3.5 \mathrm{~mm})$.

\section{StUdy ON THE OCCUPIEd SHELls}

The hermit crabs occupied shells from eleven gastropod species. Cerithium atratum (Born 1778) was significantly $(\mathrm{P}<0.05)$ the most occupied shell $(75.86 \%)$, followed by Morula nodulosa (C.B. Adams 1845) (6.03\%) and Tegula viridula (Gmelin 1791) (5.17\%).

Hermit crab occupation of gastropod shells did not differ between the sexes. Cerithium atratum shells were occupied significantly more frequently by males, ovigerous and non-ovigerous females.

Significant correlations were not obtained in all regression analysis, demonstrating sexual differences on fitting of the occupied shells. Males presented a good fitting and significant correlations in all regressions analysis while an opposite pattern was observed to the female ones. Regression analysis between non-ovigerous females and the occupied shells demonstrated low and non significant 
TABLE I

Paguristes calliopsis. Gastropod shell species occupied by the hermit crabs in the East Beach, Anchieta Island, Brazil.

\begin{tabular}{|c|c|c|c|c|c|c|c|c|}
\hline \multirow[t]{2}{*}{ Shell Species } & \multicolumn{2}{|c|}{ Total } & \multicolumn{2}{|c|}{ Males } & \multicolumn{2}{|c|}{$\begin{array}{c}\text { Non- } \\
\text { Ovigerous } \\
\text { Females }\end{array}$} & \multicolumn{2}{|c|}{$\begin{array}{l}\text { Ovigerous } \\
\text { Females }\end{array}$} \\
\hline & $\mathrm{N}$ & $\%$ & $\mathrm{~N}$ & $\%$ & $\mathrm{~N}$ & $\%$ & $\mathrm{~N}$ & $\%$ \\
\hline $\begin{array}{l}\text { Anachis lyrata } \\
\text { (Sowerby 1832) }\end{array}$ & 01 & 0.86 & - & - & - & - & 01 & 0.86 \\
\hline $\begin{array}{c}\text { Astraea latispina } \\
\text { (Philippi 1844) }\end{array}$ & 01 & 0.86 & 01 & 0.86 & - & - & - & - \\
\hline $\begin{array}{l}\text { Astraea olfersii } \\
\text { (Philippi 1844) }\end{array}$ & 04 & 3.45 & 03 & 2.59 & 01 & 0.86 & - & - \\
\hline $\begin{array}{c}\text { Astraea phoebia } \\
\text { Röding } 1798\end{array}$ & 04 & 3.45 & 04 & 3.45 & - & - & - & - \\
\hline $\begin{array}{c}\text { Calliostoma bullisi } \\
\text { Clench and Turner } 1960\end{array}$ & 01 & 0.86 & 01 & 0.86 & - & - & - & - \\
\hline $\begin{array}{l}\text { Cerithium atratum } \\
\text { (Born 1778) }\end{array}$ & 88 & 75.86 & 49 & 42.24 & 26 & 22.41 & 13 & 11.21 \\
\hline $\begin{array}{c}\text { Fusinus brasiliensis } \\
\text { (Grabau 1904) }\end{array}$ & 02 & 1.72 & 01 & 0.86 & - & - & 01 & 0.86 \\
\hline $\begin{array}{c}\text { Modulus modulus } \\
\text { (Linnaeus 1758) }\end{array}$ & 01 & 0.86 & 01 & 0.86 & - & - & - & - \\
\hline $\begin{array}{c}\text { Morula nodulosa } \\
\text { (C.B. Adams 1845) }\end{array}$ & 07 & 6.03 & 02 & 1.72 & 03 & 2.59 & 02 & 1.72 \\
\hline $\begin{array}{l}\text { Stramonita haemastoma } \\
\text { (Linnaeus 1767) }\end{array}$ & 01 & 0.86 & 01 & 0.86 & - & - & - & - \\
\hline $\begin{array}{l}\text { Tegula viridula } \\
\text { (Gmelin 1791) }\end{array}$ & 06 & 5.17 & 06 & 5.17 & - & - & - & - \\
\hline Total & 116 & 100 & 69 & 59.48 & 30 & 25.86 & 17 & 14.66 \\
\hline
\end{tabular}

correlation coefficients values, while ovigerous females presented significant correlation coefficients only to the relations between CSL and WW and shell dimensions (Table II).

Astraea phoebia Röding 1798, Astraea olfersii (Philippi 1844) and T. viridula occupied shells presented significant higher median values for SAW, SAL, SDW and internal volume in relation to $C$. atratum and M. nodulosa. No significant difference on SAL, SDW and SIV was obtained between $C$. atratum and $M$. nodulosa, the first one presented only significant higher median SAW in relation to the latter one.

Diversity of the utilized shells decreased with increasing hermit crab size (Fig. 3). C. atratum was occupied only by specimens belonging to size 


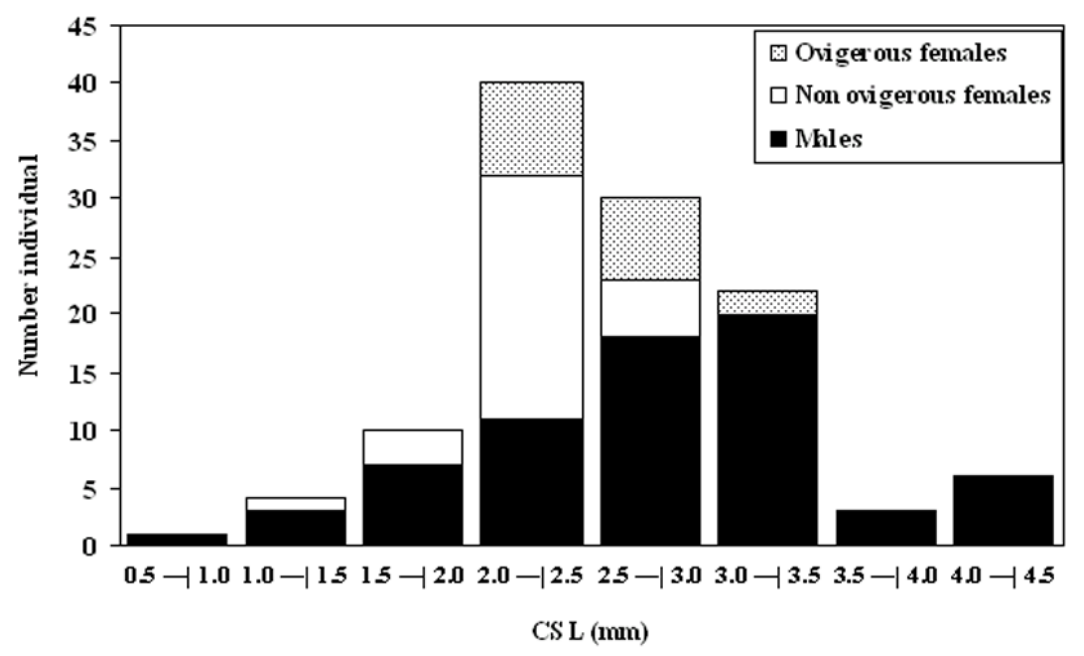

Fig. 2 - P. calliopsis. Size frequency distribution during the study period.

classes 1 to 6 . The larger individuals occupied mainly Astraea shells (Astraea latispina (Philippi 1844), A. olfersii and A. phoebia), Stramonita haemastoma (Linnaeus 1767) and Tegula viridula (Gmelin 1791) (Fig. 3).

\section{DISCUSSION}

According to Mantelatto and Garcia (2002) the type of methodology (scuba diving for capture effort) used in this study, provides large amounts of material from an irregular surface, and should be used for comparisons of anomurans from other areas. Despite the low occurrence of $P$. calliopsis, the efficiency of this sampling method revealed that the biodiversity of hermit crab species on Anchieta Island is considerably high. More than $40 \%$ of the 21 species, which have recorded for the São Paulo State coast, have been also caught in this area (Mantelatto and Garcia 2002).

Variations in diversity among monthly samples are certainly a result of the high complexity and dynamism of the studied system, associated with environmental variability. These factors, together with the adaptive processes acting on each species during evolution may be account for the variability of the anomuran community structure (Fransozo et al. 1998). This study is part of a contribution to improve the knowledge of the hermit crab communities living on the infralittoral rocky bottom (Anchieta Island, Ubatuba), in order to provide information on the biodiversity of Anomura from the São Paulo coast. In this sense, monthly exploratory collections were made throughout the year in different beaches $(n=4)$ all over the Anchieta Island. Nevertheless, the studied species presented a punctual (only in South beach) but constant occurrence. Almost all specimens, however, were located in groups of 3 or more in rocks that were regularly searched during the study.

Paguristes calliopsis is sexually dimorphic in relation to size, with males reaching larger sizes than females, corroborating the pattern reported by other authors working with related species (Bertness 1980, 1981, Manjón-Cabeza and García Raso 1996, 1998, Gherardi and Nardone 1997, Fransozo and Mantelatto 1998, Mantelatto and Garcia 2000, Mantelatto and Sousa 2000).

According to Abrams (1988), three factors can interfere in the sexual dimorphism of hermit crabs: a) the difference in energy available for growth, with males growing more because they do not expend energy in egg production, but use their full energy for structural metabolism; b) the larger reproductive ef- 


\section{TABLE II}

Paguristes calliopsis. Regression equations for the total occupied shells ( $r$ = correlation coefficient; $\mathrm{CSL}=$ cephalothoracic shield length; $\mathrm{CPL}=$ chelar propodus length; $\mathrm{CPH}=$ chelar propodus height; $\mathrm{WW}=$ hermit crab weight; $\mathrm{SAW}$ = shell aperture width; $\mathrm{SAL}=$ shell aperture length; SDW = shell dry weight; SIV = shell internal volume; $\mathrm{MA}=$ males; NOF = non-ovigerous females; $\mathrm{OF}=$ ovigerous females; $*$ = significant correlation, $\mathrm{P}<\mathbf{0 . 0 5}$ ).

\begin{tabular}{|c|c|c|c|c|}
\hline Relation & $\mathrm{N}$ & Group & $\begin{array}{l}\text { Linear equation } \\
\ln \mathrm{Y}=\mathrm{a}+\mathrm{b} \ln \mathrm{X}\end{array}$ & $\mathrm{r}$ \\
\hline SAW x CSL & 69 & MA & $\operatorname{lnSAW}=0.66+0.92 \operatorname{lnCSL}$ & $0.69 *$ \\
\hline SAW x CSL & 30 & $\mathrm{NOF}$ & $\operatorname{lnSAW}=1.22+0.891 \mathrm{lnCSL}$ & 0.07 \\
\hline SAW x CSL & 17 & $\mathrm{OF}$ & $\operatorname{lnSAW}=-0.04+1.84 \ln C S L$ & $0.76^{*}$ \\
\hline SAL X CSL & 69 & MA & $\operatorname{lnSAL}=1.48+0.60 \ln C S L$ & $0.73^{*}$ \\
\hline SAL X CSL & 30 & $\mathrm{NOF}$ & $\ln S A L=2.04-0.13 \ln C S L$ & 0.11 \\
\hline SAL X CSL & 17 & $\mathrm{OF}$ & $\operatorname{lnSAL}=0.89+1.27 \operatorname{lnCSL}$ & $0.66^{*}$ \\
\hline SDW x CSL & 69 & MA & $\operatorname{lnSDW}=-2.20+2.04 \operatorname{lnCSL}$ & $0.76^{*}$ \\
\hline SDW x CSL & 30 & $\mathrm{NOF}$ & $\operatorname{lnSDW}=-0.55-1.11 \ln \mathrm{CSL}$ & 0.05 \\
\hline SDW x CSL & 17 & $\mathrm{OF}$ & $\operatorname{lnSDW}=-1.77+1.53 \ln C S L$ & $0.60 *$ \\
\hline SIV x CSL & 33 & MA & $\operatorname{lnSIV}=-4.05+2.31 \operatorname{lnCSL}$ & $0.67 *$ \\
\hline SIV x CSL & 10 & NOF & $\operatorname{lnSIV}=-0.19-2.33 \ln C S L$ & 0.36 \\
\hline SIV x CSL & 08 & $\mathrm{OF}$ & $\operatorname{lnSIV}=-4.52+2.71 \operatorname{lnCSL}$ & $0.66^{*}$ \\
\hline SAW x WW & 69 & MA & $\operatorname{lnSAW}=2.39+0.32 \ln \mathrm{WW}$ & $0.67 *$ \\
\hline SAW x WW & 30 & $\mathrm{NOF}$ & $\operatorname{lnSAW}=1.31+0.004 \ln W W$ & 0.01 \\
\hline SAW x WW & 17 & $\mathrm{OF}$ & $\operatorname{lnSAW}=2.43+0.41 \ln W W$ & $0.52 *$ \\
\hline SAL X WW & 69 & MA & $\mathrm{LnSAL}=2.56+0.19 \ln \mathrm{WW}$ & $0.64 *$ \\
\hline SAL X WW & 30 & $\mathrm{NOF}$ & $\operatorname{LnSAL}=2.08+0.04 \ln \mathrm{WW}$ & 0.14 \\
\hline SAL X WW & 17 & $\mathrm{OF}$ & $\operatorname{LnSAL}=3.18+0.40 \ln \mathrm{WW}$ & $0.65^{*}$ \\
\hline SDW x WW & 69 & MA & $\operatorname{lnSDW}=1.68+0.74 \ln \mathrm{WW}$ & $0.75^{*}$ \\
\hline SDW x WW & 30 & $\mathrm{NOF}$ & $\operatorname{lnSDW}=-0.42+0.06 \ln \mathrm{WW}$ & 0.12 \\
\hline SDW x WW & 17 & $\mathrm{OF}$ & $\operatorname{lnSDW}=0.53+0.30 \ln \mathrm{WW}$ & 0.37 \\
\hline SIV x WW & 33 & MA & $\operatorname{lnSIV}=0.16+0.73 \ln \mathrm{WW}$ & $0.72 *$ \\
\hline SIV x WW & 10 & $\mathrm{NOF}$ & $\operatorname{lnSIV}=-1.84+0.05 \ln \mathrm{WW}$ & 0.07 \\
\hline SIV x WW & 08 & $\mathrm{OF}$ & $\operatorname{lnSIV}=-1.36+0.23 \ln \mathrm{WW}$ & 0.17 \\
\hline
\end{tabular}

fort exhibited by males may be due to their ability to fertilize more than one female; c) males of larger dimensions have a greater chance on obtaining fe- males for copulation as a function of intraspecific fights. All these factors can interfere in the size of P. calliopsis males. 
TABLE II (continuation)

\begin{tabular}{|c|c|c|c|c|}
\hline Relation & $\mathrm{N}$ & Group & $\begin{array}{l}\text { Linear equation } \\
\ln Y=a+b \ln X\end{array}$ & $\mathrm{r}$ \\
\hline SAW x CPL & 64 & MA & $\operatorname{lnSAW}=1.03+0.75 \operatorname{lnCPL}$ & $0.62 *$ \\
\hline SAW x CPL & 30 & $\mathrm{NOF}$ & $\operatorname{lnSAW}=1.22+0.24 \operatorname{lnCPL}$ & 0.13 \\
\hline SAW x CPL & 17 & $\mathrm{OF}$ & $\operatorname{lnSAW}=0.93+0.79 \operatorname{lnCPL}$ & $0.59 *$ \\
\hline SAL X CPL & 64 & MA & $\mathrm{LnSAL}=1.69+0.54 \operatorname{lnCPL}$ & $0.69^{*}$ \\
\hline SAL X CPL & 30 & NOF & $\mathrm{LnSAL}=2.00-1.17 \operatorname{lnCPL}$ & 0.12 \\
\hline SAL X CPL & 17 & OF & $\mathrm{LnSAL}=1.81+0.54 \operatorname{lnCPL}$ & $0.51 *$ \\
\hline SDW x CPL & 64 & MA & $\operatorname{lnSDW}=-1.41+1.72 \operatorname{lnCPL}$ & $0.69^{*}$ \\
\hline SDW x CPL & 30 & NOF & $\operatorname{lnSDW}=-0.60-0.12 \operatorname{lnCPL}$ & 0.05 \\
\hline SDW x CPL & 17 & $\mathrm{OF}$ & $\operatorname{lnSDW}=-0.62+0.70 \operatorname{lnCPL}$ & $0.50^{*}$ \\
\hline SIV x CPL & 33 & MA & $\operatorname{lnSIV}=-3.34+2.31 \operatorname{lnCPL}$ & $0.76^{*}$ \\
\hline SIV x CPL & 10 & $\mathrm{NOF}$ & $\operatorname{lnSIV}=-1.51-1.54 \operatorname{lnCPL}$ & 0.28 \\
\hline SIV x CPL & 08 & $\mathrm{OF}$ & $\operatorname{lnSIV}=-2.57+1.20 \operatorname{lnCPL}$ & 0.38 \\
\hline SAW x CPH & 64 & MA & $\operatorname{lnSAW}=1.45+0.73 \mathrm{LCPH}$ & $0.63^{*}$ \\
\hline SAW x CPH & 30 & $\mathrm{NOF}$ & $\operatorname{lnSAW}=1.31+0.08 \mathrm{LCPH}$ & 0.06 \\
\hline SAW x CPH & 17 & $\mathrm{OF}$ & $\operatorname{lnSAW}=1.27+0.40 \mathrm{LCPH}$ & 0.27 \\
\hline SAL X CPH & 64 & MA & $\mathrm{LnSAL}=2.00+0.49 \operatorname{lnCPH}$ & $0.64^{*}$ \\
\hline SAL X CPH & 30 & $\mathrm{NOF}$ & $\mathrm{LnSAL}=1.93-0.091 \mathrm{nCPH}$ & 0.07 \\
\hline SAL X CPH & 17 & OF & $\mathrm{LnSAL}=2.04+0.46 \operatorname{lnCPH}$ & 0.37 \\
\hline SDW x CPH & 64 & MA & $\operatorname{lnSDW}=-0.45+1.67 \operatorname{lnCPH}$ & $0.69^{*}$ \\
\hline SDW x CPH & 30 & $\mathrm{NOF}$ & $\operatorname{lnSDW}=-0.61+0.12 \ln \mathrm{CPH}$ & 0.06 \\
\hline SDW x CPH & 17 & $\mathrm{OF}$ & $\operatorname{lnSDW}=-0.32+0.34 \operatorname{lnCPH}$ & 0.21 \\
\hline SIV x CPH & 33 & MA & $\operatorname{lnSIV}=-2.08+2.28 \operatorname{lnCPH}$ & $0.82 *$ \\
\hline SIV x CPH & 10 & NOF & $\operatorname{lnSIV}=-2.06-0.25 \ln \mathrm{CPH}$ & 0.05 \\
\hline SIV x CPH & 08 & OF & $\operatorname{lnSIV}=-1.99+0.11 \operatorname{lnCPH}$ & 0.05 \\
\hline
\end{tabular}

In the present study the $1.47: 1$ sex ratio resulted value differs from the expected value $(1: 1)$. However, most of crustacean populations highlight sex ratios differing from 1:1 (Wenner 1972). The search for and utilization of shells is the major adaptation of the hermit crabs, one sex (generally the males) being more successful in obtaining shells (Bertness 1981). Although the sex-ratio analysis shows an increase of male proportion at larger sizes, in the intermediate class (2.0 to $2.5 \mathrm{~mm}$ ) females prevailed. This pattern has been the most common one reported in the literature (Wenner 1972, Manjón-Cabeza and García Raso 1995, Gherardi and Nardone 1997, Fransozo and Mantelatto 1998) for hermit crab populations inhabiting both the intertidal and infralittoral areas. This and the unequal sex-ratio probably can be attributed by such factors as differential mortality and growth rates between 


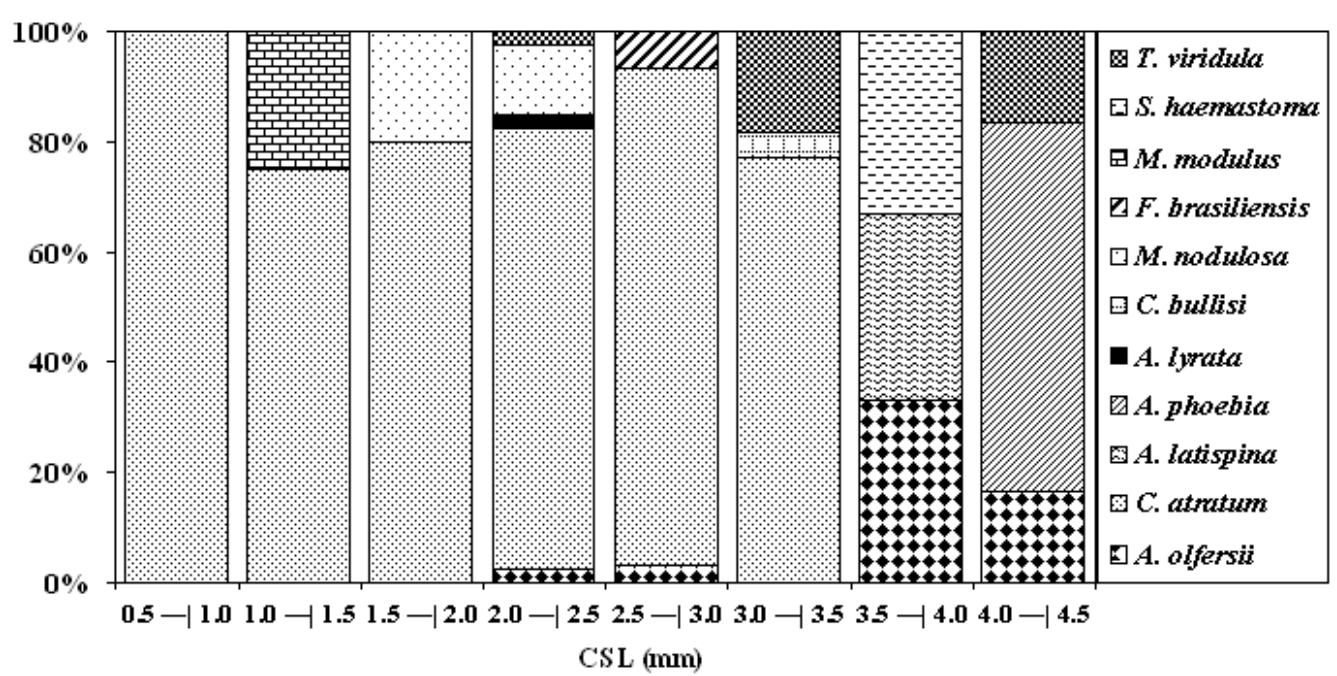

Fig. 3 - P. calliopsis. Shell occupation as a function of hermit crab size.

sexes and migrations (Wenner 1972, Hartnoll 1982), with males reaching larger sizes in less time than females but being influenced by shell limitation.

The population dynamics of the hermit crabs is strongly related to the gastropod shell utilization process. The most occupied shells by $P$. calliopsis were: Cerithium atratum $(75.86 \%, \mathrm{P}<0.05)$, Morula nodulosa (6.03\%) and Tegula viridula (5.17\%). Despite the high variety of shell resources presented in the area (Meireles et al. 2003), $P$. calliopsis occupied mainly the two most available species of the area. Moreover, one of these species (C. atratum) was occupied by 5 of the 9 hermit crab species that live at Anchieta Island (Mantelatto and Garcia 2002). Herewith, there is a habitat overlap and, consequently sharing of resources by the different species, resulting the occurrence of fights for shells and the occupancy of damage ones.

The small sized hermit crab individuals mainly occupied Cerithium atratum shells, as a function of their small volumetry. Specimens of large size classes occupied Astraea (A. latispina, A. olfersii and A. phoebia), S. haemastoma and T. viridula shells reflecting the higher size of these shells species. The higher diversity of shell species occupation by small and intermediate-sized individu- als may be due to the poor intraspecific competitive ability of the latter (Dowds and Elwood 1983) or to the low availability of high-sized shells in this area (Mantelatto and Meireles 2004). Furthermore, Astraea shells (A. latispina, A. olfersii, A. phoebia) represented approximately $65 \%$ of the empty shells found in this area (Meireles et al. 2003).

Males and females (ovigerous and nonovigerous) occupied mainly the same shell species, and there was no difference in the shell species preference between the sexes. Nevertheless, differences in the shell utilization pattern according to hermit crab sexes has been found elsewhere (Gherardi 1991, Imazu and Asakura 1994, Mantelatto and Garcia 2000, Benvenuto and Gherardi 2001, Mantelatto and Dominciano 2002) and may be explained by the differences in the maximum size of individuals, by the competitive ability (Bertness 1981) or by the reproductive behavior (Imazu and Asakura 1994).

The size of the occupied shells is usually quite well correlated with the hermit crab size in the field (Hazlett 1981). Positive correlation between hermit crab size and shell measure was reported. Despite no significant difference in shell type utilization between sexes was observed, significant corre- 
lations in all regression analysis were obtained only to males. This may reflect that males choose the shells that best fit (shell size preference) them associated to the type availability in the survey, but laboratory experiments are needed to test this hypothesis.

The low shell size association (non significant correlation coefficients) obtained to the non-ovigerous females may demonstrate that: 1) the shell size dimensions are not important to determine its occupation, 2) they occupy shells according to the type availability in the survey, 3) they occupy shells that are the least preferred, and thus avoiding competition, and/or 4) they occupy shells in function of other parameters not measured in the present study.

Ovigerous females' regression analysis demonstrated positive and significant correlations to the association between hermit crab shield length and weight and shell dimensions evidencing a better fitness than the non-ovigerous females. That shell dimensions affect important aspects (growth and reproduction) of the females life cycle is well known in the literature survey (Fotheringham 1976, Hazlett 1981, Bertness 1981, Wilber 1989, Reddy and Biseswar 1993, Elwood et al. 1995, Iossi et al. 2005). In this study we may consider that $P$. calliopsis ovigerous females occupied good fitted shells possibly in function of its advantage to the reproduction process (egg production and storage) once the non-ovigerous did not present such shell adequacy.

Reported information suggests that the shell occupation by $P$. calliopsis occurred in function of the shell-type availability and might be influenced by the differences between hermit crab sizes. Previous studies on species living in the same area such as Paguristes tortugae Schmitt 1933 (Mantelatto and Dominciano 2002), Pagurus brevidactylus (Stimpson 1859) (Mantelatto and Meireles 2004) and Paguristes erythrops Holthuis 1959 (Garcia and Mantelatto 2001) revealed the same pattern of shell adequacy. The shells availability and the interspecific relationships are the main factors responsible for the maintenance of the hermit crabs community of Anchieta Island.

In the studied area we observed that Paguristes species are coexistent and present resource (shells) and niche overlaps (Mantelatto and Garcia 2002). However, the P. calliopsis population in less abundant than the others and occupy the same shell species in high percentage (C. atratum and M. nodulosa) as $P$. tortugae. The latter one attains larger size, occupy a wider variety of shell species and correspond to the most abundant hermit population in Anchieta Island (Mantelatto and Dominciano 2002, Mantelatto and Garcia 2002). This probably indicates that despite the close relationship between the Paguristes hermit crabs in Anchieta Island, one (P. tortugae) may have developed strategy to guarantee high density and other (P. calliopsis) survivorship.

In the marine provinces of the Western Atlantic, the genus Paguristes exhibits the greatest degree of species proliferation of all the diogenid genera. However, some of these species are closely allied ones and can be inserted in complexes that reflect their morphological similarity (McLaughlin and Provenzano-Jr 1974) but not ecological ones necessarily. One of these complexes is the Paguristes tortugae that includes the studied species $P$. calliopsis. In this way, the biological features of $P$. calliopsis reported here for the first time is important to understand the biology of this species. However, data on reproduction (reproductive period, fecundity, temporal occurrence) as well as some other aspects concerning its life cycle may contribute to the knowledge of this species and the Paguristes complex relationship along the western Atlantic coast.

\section{ACKNOWLEDGMENTS}

The authors are grateful to Fundação de Amparo à Pesquisa do Estado de São Paulo (FAPESP) for financial support during field work to FLM (Grant 98/07454-5) and for a Master and a Doctoral Fellowship to ALM (Proc. 99/11679-5) and RB (Proc. 00/02554-3), respectively. FLM and RB received research and post-doctoral scholarships, respecti- 
vely, from Conselho Nacional de Desenvolvimento Científico e Tecnológico (CNPq). Thanks are due to Secretaria do Meio Ambiente do Estado de São Paulo, IBAMA and Parque Estadual da Ilha Anchieta for permission (Proc. 42358/98) during the sampling work. Special thanks are due to Dr. Osmar Domaneschi (Zoology Department, IB-USP) for assistance with shell identification, to all colleagues of the Laboratory of Bioecology and Crustacean Systematics - FFCLRP/USP for their help during field and laboratory work. All experiments conducted in this study comply with current applicable state and federal laws.

\section{RESUMO}

Os estudos sobre a biologia dos ermitões no Atlântico sul ocidental são escassos considerando-se a biodiversidade local. O presente trabalhou caracterizou a população do ermitão Paguristes calliopsis Forest and Saint Laurent, 1968 quanto à distribuição de freqüência de tamanho dos indivíduos, ao sex-ratio, e a ocupação das conchas no ambiente natural. Os exemplares foram coletados por mergulho autônomo na região infralitoral da Ilha Anchieta. Um total de 116 indivíduos foi analisado. O tamanho do comprimento do escudo cefalotorácico (mínimo; máximo; média \pm sd, respectivamente) dos indivíduos variou de: $0.8 ; 4.5 ; 2.76 \pm 0.79 \mathrm{~mm}$ para machos e 2.28 $\pm 0.36 \mathrm{~mm}$ para fêmeas. O sex-ratio foi de $1.47: 1 \mathrm{em}$ favor dos machos, sendo estes os que prevaleceram nas maiores classes de tamanho. Os ermitões ocuparam conchas de 11 espécies de gastrópodes sendo Cerithium atratum (Born 1778) significativamente a concha mais ocupada $(75.86 \%)$. Não foram obtidas correlações significativas em todas as análises de regressão, demonstrando diferenças entre os grupos sexuais quanto a adequação das conchas ocupadas. Na área estudada a população de $P$. calliopsis pode ser considerada pequena quando comparada com as outras populações coexistentes. O padrão de utilização de conchas variou em função da disponibilidade destas e da competição interespecífica.

Palavras-chave: Diogenidae, Paguristes, população, ocupação concha.

\section{REFERENCES}

ABRAMS PA. 1988. Sexual difference in resource use in hermit crabs: consequences and causes. In: CHELAZZI G AND VANNINI M (Eds), Behavioral adaptations to intertidal life, New York: Plenum Press, p. 283-296.

Benvenuto C and Gherardi F. 2001. Population structure and shell use in the hermit crab, Clibanarius erythropus: a comparison between Mediterranean and Atlantic shores. J mar Biol Ass UK 81: 77-84.

BERTNESS MD. 1980. Shell preference and utilization patterns in littoral hermit crabs of the Bay of Panama. J exp mar Biol Ecol 48: 1-16.

BERTNESS MD. 1981. The influence of shell-type on hermit crab growth rate and clutch size. Crustaceana 40: 197-205.

DowdS BM AND ELWOOD RW. 1983. Shell wars: assessment strategies and the timing of decisions in hermit crab shell fights. Behavior 85: 1-24.

Elwood RW, MARKS N AND Dick JTA. 1995. Consequences of shell-species preferences for female reproductive success in the hermit crab Pagurus bernhardus. Mar Biol 123: 431-434.

Fransozo A and Mantelatto FL. 1998. Population structure and reproductive period of the tropical hermit crab Calcinus tibicen (Decapoda: Diogenidae) in the region of Ubatuba, São Paulo, Brazil. J Crust Biol 18: 738-745.

Fransozo A, Mantelatto FL, Bertini G, FerNANDES-Góes L AND MARTinelli JM. 1998. Distribution and assemblages of anomuran crustaceans in Ubatuba Bay, north coast of São Paulo State, Brazil. Acta Biol Venez 18: 17-25.

Fotheringham N. 1976. Population consequences of shell utilization by hermit crabs. Ecology 57: $570-578$.

Garcia RB And Mantelatto FL. 2000. Variability of shell occupation by intertidal and infralittoral $\mathrm{Cal}$ cinus tibicen (Anomura, Diogenidae) populations. Nauplius 8: 99-105.

Garcia RB and Mantelatto FL. 2001. Population dynamics of the hermit crab Paguristes erythrops (Diogenidae) from Anchieta Island, Southern Brazil. J mar biol Ass UK 81: 955-960. 
GHERARDI F. 1991. Relative growth, population structure, and shell utilization of the hermit crab Clibanarius erythropus in the Mediterranean. Oebalia 17: 181-196.

Gherardi F And NARdone F. 1997. The question of coexistence in hermit crabs: population ecology of a tropical intertidal assemblage. Crustaceana 70 : 608-629.

HaRtnoll RG. 1982. Growth. In: Bliss DE (Ed), The biology of Crustacea, Embryology, Morphology, and Genetics, New York: Academic Press 2: 11-196.

HaZlett BA. 1981. The behavioral ecology of hermit crabs. Annu Rev Ecol Syst 12: 1-22.

Hebling NJ, Mantelatto FL, Negreiros-FranSOZO ML AND FRANSOzO A. 1994. Levantamento e distribuição de braquiúros e anomuros (Crustacea, Decapoda) dos sedimentos sublitorais da região da Ilha Anchieta, Ubatuba (SP). Bolm Inst Pesca 21: 01-09.

HendrickX ME AND HaRveY AW. 1999. Checklist of anomuran crabs (Crustacea: Decapoda) from Eastern Tropical Pacific. Belg Jour Zool 129: 363-389.

IMAZU M AND ASAKURA A. 1994. Distribution, reproduction and shell utilization patterns in three species of intertidal hermit crabs on a rocky shore on the $\mathrm{Pa}$ cific coast of Japan. J exp mar Biol Ecol 184: 41-65.

Iossi CL, Biagi R And Mantelatto FL. 2005. Egg production and shell relationship of the hermit crab Pagurus brevidactylus (Anomura: Paguridae) from southern Brazil. Anim Biol 55: 111-121.

LANCASTER I. 1988. Pagurus bernhardus (L.) - An introduction to the natural history of hermit crabs. Field Stud 7: 189-238.

MAnjón-CABEZA ME And García RAso JE. 1995. Study of Calcinus tubularis (Crustacea, Diogenidae) from a shallow Posidonia oceanica meadow. Cah Biol Mar 36: 277-284.

MAnjón-CABEZA ME AND GARCíA RASo JE. 1996. Study of size relationships and relative growth of Cestopagurus timidus (Roux). A method for separating groups (Crustacea, Decapoda, Anomura). Spixiana 19: 239-248.

MAnJón-CABEZA ME ANd GARCía RAso JE. 1998. Population structure and growth of the hermit crab Diogenes pugilator (Decapoda: Anomura: Dioge- nidae) from the north-eastern Atlantic. J Crust Biol 18: 753-762.

Mantelatto FL And Dominciano LCC. 2002. Pattern of shell utilization by the hermit crab Paguristes tortugae (Diogenidae) from Anchieta Island, southern Brazil. Sci Mar 66: 265-272.

Mantelatto FL And Fransozo A. 2000. Brachyuran community in Ubatuba Bay, Northern Coast of São Paulo State, Brazil. J Shellfish Res 19: 701709.

Mantelatto FL and Garcia RB. 2000. Shell utilization pattern of the hermit crab Calcinus tibicen (Diogenidae) from southern Brazil. J Crust Biol 20: 460-467.

Mantelatto FL AND GaRCiA RB. 2002. Hermit crab fauna from the infralittoral area of Anchieta Island (Ubatuba, Brazil). In: Briones EE AND ALvAREZ F (Eds), Modern Approaches to the Study of Crustacean, Kluwer Academic/Plenum Publishers, New York, p. 137-144.

Mantelatto FL And Meireles AL. 2004. The importance of shell occupation and shell availability in the hermit crab Pagurus brevidactylus (Stimpson, 1859) (Paguridae) population from the southern Atlantic. Bull mar Sci 75: 27-35.

Mantelatto FL And Sousa LM. 2000. Population biology of the hermit crab Paguristes tortugae Schmitt, 1933 (Anomura, Diogenidae) from Anchieta Island, Ubatuba, Brazil. Nauplius 8: 185-193.

McLaughlin PA And Provenzano JR AJ. 1974. Hermit crabs of the genus Paguristes (Crustacea: Decapoda: Diogenidae) from the western Atlantic. Part I. The Paguristes tortugae complex, with notes on variation. Bull Mar Sci 24: 165-234.

Meireles AL, Biagi R And Mantelatto FL. 2003. Gastropod shell availability as a potential resource for the hermit crab infralittoral fauna of Anchieta Island (SP), Brazil. Nauplius 11: 99-105.

Melo GAS. 1999. Manual de identificação dos Crustacea Decapoda do litoral brasileiro: Anomura, Thalassinidea, Palinuridea e Astacidea. Editora Plêiade, São Paulo, SP, Brasil, 551 p.

MILLER RS. 1967. Pattern and process in competition. Adv Ecol Res 4: 1-74.

Negreiros-Fransozo ML, Fransozo A, Mante- 
LATTO FL, PinHeiro MAA AND SANTOS S. 1997. Anomuran species (Crustacea, Decapoda) and their ecological distribution at Fortaleza Bay subllitoral, Ubatuba, São Paulo, Brazil. Iheringia Sér Zool 83: 187-194.

Provenzano JR AJ. 1978. Larval development of the hermit crab Paguristes spinipes Milne-Edwards, 1880 (Decapoda, Diogenidae) reared in laboratory. Bull Mar Sci 28: 512-526.

REDDY T AND BISESWAR R. 1993. Patterns of shell utilization in two sympatric species of hermit crabs from the Natal coast (Decapoda, Anomura, Diogenidae). Crustaceana 65: 13-24.
RIOS EC. 1994. Seashells of Brazil. Rio Grande do Sul. Fundação cidade do Rio Grande, Instituto Acqua, Museu Oceanográfico de Rio Grande, Universidade de Rio Grande, $2^{\mathrm{a}}$ ed., 368 p.

WENNER AM. 1972. Sex ratio as a function of size in marine Crustacea. Am Nat 106: 321-350.

WILBER JR TP. 1989. Associations between gastropod shell characteristics and egg production in the hermit crab Pagurus longicarpus. Oecologia 81: 6-15.

ZAR JH. 1996. Biostatistical Analysis. Prentice-Hall, New Jersey, 907 p. 